\title{
The Concept of Death in John Donne and Sohrab Sepehri: A Comparative Study
}

\author{
Behnam Mirzababazadeh Fomeshi \\ Department of Foreign Languages and Linguistics, Faculty of Humanities, Shiraz University, Shiraz, IRAN \\ e-mail: behnam.mirzababazadeh@gmail.com
}

\begin{abstract}
Death has always permeated human's thoughts at all levels. This preoccupation with death is manifested in the realm of literature. John Donne is one of the artists whose obsession with death is universally recognized. The contemporary Iranian poet, Sohrab Sepehri, in some of his poems employs the subject, too. Unlike Donne, Sepehri is not known as a 'death poet.' Although he lives in a turbulent period in the history of Iran, he is not influenced by his immediate condition. While the English poet is inconsistent in his treatment of death, Sepehri is consistent in his treatment of death. Sepehri's consistency in the treatment of death has something to do with his religious beliefs. The reason behind Sepehri's consistency in treating death as a positive phenomenon is his familiarity with the Islamic Sufism and eastern mysticisms.
\end{abstract}

Keywords: Donne, Sepehri, comparative, death, Persian poetry

\section{INTRODUCTION}

Death is an inevitable destiny for human, and for this reason it has always permeated his/her thoughts at all levels. This preoccupation with death is manifested in the realm of literature. Among the most persistently treated subjects in the literary world, death exists as one of the determining features in the writing of poets, dramatists, and novelists. Intertwined with the origins of literature itself, human consciousness of mortality has for centuries provided the impetus for reflection on the causes, meanings, and nature of existence. While treatments of death are as varied as the authors who employ it, scholars have perceived in literary texts - whether for the stage, in verse, or in prose fiction - certain clearly defined approaches to this topic of universal interest.

John Donne (1572-1631), the greatest metaphysical poet, is one of the artists whose obsession with death is universally recognized. His preoccupation with the instability of life and the ruthless perpetuity of death makes him a death-poet. Two of his most famous phrases are "death be not proud" and "for whom the bell tolls," and thirty-two of his fifty-four songs and sonnets center on the theme. Ralph Waldo Emerson (1803-1882), the American transcendentalist, calls him a "philosopher" (as cited in Hammond, 1974, p. 68), and Samuel Taylor Coleridge (1772-1834), the British romantic poet, views him as "worthy almost of
Shakespeare" (as cited in Smith, 1983, p. 278). These two quotations reveal Donne's status in the world of literature. The contemporary Iranian poet, Sohrab Sepehri (1928-1980), in some of his poems employs the subject. In one of his most famous poems, "The Sound of the Water's Step," he talks about life, death, and other fundamental questions of human. $\mathrm{He}$ believes "if there was no death, our hands would look for something" (Sepehri, 2007, p. 294). Through analyzing the works of these two poets the present paper is an attempt toward discovering their attitudes toward death - to compare and to contrast them.

\section{DEATH IN DONNE}

Donne experienced many personal tragedies. He was born into a terror (Carey, 1990, p. 18). In 1576 his father died when the son was only four. In 1577, his sister Elizabeth died, followed by two more of his sisters, Mary and Katherine, in 1581. Before the future poet was ten years old he had thus experienced the deaths of four of his immediate family. His brother had died of a fever in prison after harboring a Roman Catholic priest, and an uncle, a Jesuit, was hanged, castrated, disemboweled, and quartered (Greenblatt et al, 2006, p. 1260). Queen Elizabeth's government, though by contemporary standards tolerant, still uniformly burdened Catholics with harassment and financial penalties. This fact may be one of the underlying reasons of Donne's "religious 
doubts" (Ponder, 1998, p. 192). Most of his marriage was spent in poverty. Five of his twelve children died during birth or infancy. Donne endured his wife Ann's miscarriages, and in 1617 her own death at the age of thirty-three (Greenblatt et al, 2006, p. 1261), just a year after he took his first parish job. In his funeral sermon for her, he preached from Lamentations, "I am the man that hath seen affliction". Before her death, Ann bore him eleven children. The nine living were named Constance, John, George, Francis, Lucy, Bridget, Mary, Nicholas and Margaret. Francis and Mary died before they were ten. Throughout these years, religious conflicts continued around and within the Church of England, and plagues regularly attacked London and the countryside. Donne was often ill himself.

Donne's principal literary accomplishments during this period was Divine Poems (1607) and the prose work Biathanatos (c. 1608, posthumously published 1644), a half-serious extenuation of suicide, in which he argued that suicide is not intrinsically sinful. So it is not surprising that Donne often had death on his mind. What's remarkable is how he used the subject as a facilitator for meditations on all aspects of the Christian life. According to Sugg (2007), "throughout his writing [Donne] frequently seems to have not one, but two feet firmly in the grave, and indeed digging himself into it with creative zeal" (p. 187).

The bereavements Donne experienced, the harassment of the Catholics, his poverty, and the plagues which regularly attacked London are not the only reasons of his preoccupation with death. Sugg (2007) refers to Donne's "almost scientific curiosity about the process by which the human soul will be liberated, re-embodied, and taken into the eternal, crystalline purity and bliss of that heaven which, for many Christians, was the real world, and real life" (p. 192) as the reason for the poet's fascination with death. Rugoff (1962) also numbers some reasons for Elizabethan and Jacobean writers' melancholy or morbid consciousness of death. He mentions to "the depression and cynicism of spirit that seems to follow areas which, like the Elizabethan, are characterized by the inordinate expansion in every direction; and life still itself regarded as cheap as ever by disease and war, the former raging unchecked, the latter accepted like daily bread"' (p. 234).

Donne's works include love poetry, sermons and religious poems, Latin translations, epigrams, elegies, songs and sonnets. The present paper refers to Holy Sonnet X, Devotion Upon Emergent Occasions, Death Duel, Holly Sonnet XVII, and A Nocturnal Upon Saint Lucy's Day.

\section{Holy Sonnet X}

"Death Be Not Proud" is a sonnet that varies significantly from typical sonnets. It is not one of love and romance; it can be said that Donne is romanticizing the idea of death. Donne's "famously impassioned 'Holy Sonnets' showed how the religious poet might appropriate traditionally secular lyric genres" (Keenan, 2008, p. 135). He frequently employs connotation to demonstrate his contempt for death's pride, and to emphasize the powerlessness of death. Throughout the poem, death is described as rest and sleep, implying the weakness of death, and the transience of its effects. Both rest and sleep give us pleasure and this unusual comparison can be an example of metaphysical conceit. Donne uses pleasure to depict what death must be like, implying that not only is death not to be afraid of, but it is also a pleasant experience.

Death is a slave. The definition of a slave is someone who must adhere to another's wishes, and therefore Donne is showing the absence of genuine dominance or authority of death. He employs metaphor to compare death's methods to poppy or charms. This connotation describes that the feeling of death is not inevitably unpleasant; and poppy or charms both imply a peaceful and relaxed passing into sleep or death, therefore extremely lessening the fear of death. The metaphor explains that since sleep is such a pleasant experience, death must be even more pleasant, since Donne believes that death is simply a deeper form of sleep. A method used by Donne to diminish the fear of death is to compare it to sleep. He uses metaphors frequently in the sonnet to compare death to sleep. Through comparing the unknown phenomena to a known one he conveys a feeling of familiarity with death, an acceptance through understanding, and therefore removing the fear of the unknown.

Donne attacks the immortality and pride of death when he writes, "Thou art slave to fate, chance, kings, and desperate men." This comparison makes death appear to be subordinate to forces other than its own, particularly the forces of man. By making death appear to depend on man, Donne shows the reader that rather than death being overpowering, man is in fact more in control of death than death is itself. $\mathrm{He}$ also compares the relationship of death to the afterlife to that of sleep to waking up. This comparison is also found in Sepehri. This metaphor encompasses the religious aspect of the theme by showing that death is not permanent, but is only a break between life in this world and the next. Donne "affirms with great bravado the ultimate defeat of death through eternal life" (Targoff, 2008, p. 106). 
The most important element of Holy Sonnet $X$ is the poet's use of apostrophe. To address death is evident from the beginning line of the sonnet, "Death, be not proud, though some have called thee" to "thou shalt die" which ends it. This address shows the attitude of the poet towards death throughout the poem by making the audience immediately aware that death is not in such a high position that cannot be addressed by a mortal. Through personification, Donne questions death's power. Using "thee" Donne puts death at the same level as himself, and demonstrates his lack of fear and awe for death. Donne succeeds in escaping his fear of death by deriding it. As a devout Christian, Donne considers death the indispensable transitional period, something neither to be annoyed about nor to be afraid of.

\section{Devotion Upon Emergent Occasions}

Raspa (2007) believes Devotions upon Emergent Occasions "provides a powerful psychological analysis of the nearly fatal illness Donne suffered from late November to early December 1623" (as cited in Jungman, 2007, pp. 16-17). Written while Donne recovered from a life-threatening fever, Devotions upon Emergent Occasions alternates descriptions of bodily decay and medicinal treatment with broader thoughts on the human condition and prayers for spiritual healing. Imagining himself in a "losing duel with death" (Trevor, 2000, p. 85), Donne tries to find a solution to conquer and defeat death (Zhang \& Wang, 2011, p. 861). One of the most prevalent works in which metaphysical conceit is used is John Donne's Meditation 17. In this work, Donne compares human life to a chapter in a book. He writes:

"All mankind is of one author and is one volume; when one man dies, one chapter is not torn out of the book, but translated into a better language; and every chapter must be so translated. God employs several translators ... but God's hand is in every translation, and his hand shall bind up all our scattered leaves again for that library where every book shall lie open to one another" [italics mine] (as cited in Abrams, 1987, p. 622).

Unlike Holy Sonnet $X$ this text does not ridicule death. Neither does it demonstrate Donne's contempt for death's pride, nor does it emphasize the powerlessness of death. Death, here, is a translation into a better language. It is a must, and God's hand is seen in the translation. So death becomes at the same time inevitable and desirable. Meditation 17 is written by an old religious man. One should bear in mind that when Donne writes Devotions he is fifty-one years old and the dean of St. Paul's Cathedral.

\section{Death's Duel}

After his ordination, Donne wrote a number of religious works, such as this. The collection consists of twenty-three 'stations', each of three parts: a meditation, an expostulation and a prayer. Each 'station' shares a similar dynamic. Thus "in the opening 'meditations' Donne's illness generally prompts him to spiritual contemplation on themes suggested by his suffering, such as mortality, personal sinfulness and salvation" (Keenan, 2008, p. 203). Several of these sermons were published during his lifetime. Donne was also regarded as one of the most eloquent preachers of his day.

In 1621, Donne was made dean of St. Paul's, a position he held until his death. His sermons are still considered as one of the high points of seventeenthcentury English prose. The Sermons, 160 in all, are especially memorable for their imaginative explications of biblical passages and for their intense explorations of the themes of divine love and of the decay and resurrection of the body.

Donne's final sermon, Death's Duel, delivered at the beginning of Lent, was particularly effective, as the preacher himself was near death from stomach cancer. Through the work he described in "such vivid terms death's eventual defeat through resurrection" (Targoff, 2008, p. 156). With that sermon, Donne effectively conducted his own funeral. Death's Duel, "Donne's greatest sermon" (Rugoff, 1962, p. 179), portrays life as a steady descent to suffering and death, yet sees hope in salvation and immortality through an embrace of God, Christ and the Resurrection. In this sermon death is viewed as "a birth - a beginning, for some, of immortal life" ( $p$. 179). Since Death's Duel is a sermon preached by the dean of St. Paul's Cathedral, it views death from a religious point of view and refers to immortality and the resurrection after it.

\section{Holy Sonnet XVII}

Donne's wife's death in 1617 was a prolific source of inspiration for Donne's poetry. Holy Sonnet XVII is entirely dedicated to her loving memory. In Holy Sonnet XVII, his visions of death are different from his visions of death in Holy Sonnet $X$, Devotion Upon Emergent Occasions, and Death Duel since an attempt to come to terms with his wife's absence forces yet another search of death's significance. According to Donne, "heaven behaves as a murdering rapist" (Anderson, 1995, p. 2) and he "cannot feel secure in a God that took away his happiness" (p. 3). 
Unlike Holy Sonnet X, neither does this Holy Sonnet ridicule death, nor does it emphasize the powerlessness of death. On the contrary, it depicts death's power and dominion on human. Unlike Meditation $X V I I$ death, it is not a translation into a better language. God's hand is seen in death, but this does not make death desirable. Here it works differently. Sugg (2007) believes Donne's "sorrow could be inordinate and dangerous because it constituted an effective grudging at God's wisdom and ultimate beneficence" (p. 189). Donne does not see hope in salvation and immortality through an embrace of God, Christ and the Resurrection as he sees in Death's Duel. It voices "anxious fears about his salvation or about his desperate sins and helplessness" (Greenblatt et al, 2006, p. 1606).

\section{A Nocturnal upon Saint Lucy's Day}

The poem "A Nocturnal upon St. Lucy's Day" concerns the poet's "despair at the death of a loved one. The poem is the quintessence of nothingnessdeath in the world, and for the world" (Andreasen, 1967 , p. 155). This famous work was probably written in 1627 when both Donne's friend, Lucy, Countess of Bedford, and his daughter, Lucy Donne, died. Andreasen believes "[t]he biographical reading of Donne has encouraged the assumption that ... 'A Nocturnal upon S. Lucies Day' is addressed to the Countess of Bedford" (p. 10). Edgecombe (1994) regards Ann, Donne's wife, who died on August 15, 1617 as the subject. Although there is not consensus on the person, she must be a loved one. "[N]octurns were held at midnight ... in celebration of the festival of St. Lucy, beheaded as a virgin martyr during the persecution of Diocletian" (Andreasen, 1967, p. 154). A Nocturnal, fully and profoundly a masterpiece of Donne's individual poetic imagination (Stein, 1965, p. 178), neither does ridicule death, nor does it emphasize the powerlessness of death, nor does see death as a translation into a better language. Donne does not see hope in salvation and immortality through an embrace of God, Christ and the Resurrection as he sees in Death's Duel. It is a "refusal to believe in the possibility of renewal, an implied refusal to believe in the possibility of redemption and resurrection" (Andreasen, 1967, p. 160). Andreasen (1967) considers his condition as one of "total hopelessness, total despair, total depression' (p. 160). It is a "full-scale lyric exercise in self-annihilation” (Stein, 1965, p. 178).

Carey (1990) believes Donne's "aim when he writes about death, is to make it more active and positive than life, and so negate its deathliness" (p. 186), and Gosse (2008) believes "the spirit of this strange writer loved to dwell on the majestic and gorgeous aspects of death, to wave his torch within the charnel-house and to show that its walls are set with jewels," (p. 99). However, it is not always the case. It is not always the jewels which are shown. The first three works discussed may support Carey and Gosse, but the next two works discussed contradict Carey and Gosse and make the readers see the other side of Donne. In one of his sonnets, he shows the absence of genuine dominance or authority of death, and demonstrates his lack of fear and awe for death while in another death's power and dominion on human is depicted. In one work he sees hope in salvation and immortality through an embrace of God, Christ and the Resurrection while another work is "a refusal to believe in the possibility of redemption and resurrection" (Andreasen, 1967, p. 160). In a sermon, death is viewed as "a birth-a beginning, for some, of immortal life" (Rugoff, 1962, p. 179) while in a poem as a symbol for the destruction of the universe. Donne did not confine himself to the majestic and gorgeous aspects of death. He, in fact, fluctuated between two opposing attitudes toward death.

\section{DEATH IN SEPEHRI}

The outcome of Sepehri's poetic career is his cycle of poems entitled: "The Eight Books," including: "Death of Colors," "The Life of Dreams," "The Ruin of the Sun," "The East of Grief," "The Sound of the Water's Step," "Traveler," "The Green Volume," and "We Nothing, But Look." "Death of Colors" is the first collection of Sepehri's poetry published in 1951 and revised and republished a few years later. As the title shows, the poems of "Death of Colors" have been under the influence of the social and political life of the era prior to the August 18, 1953 Coup. The most important characteristic of the Persian poetry of that period is that the majority of the poets were tending to use in their poems such symbols as night, darkness, loneliness, silence, cold, tyranny, defeat, dictatorship, imprisonment, and the like.

Sepehri's second collection of poems, published in 1953, is entitled 'The Life of Dreams.' Unlike his first collection, here life replaces death as illuminating elements are supplanted by light, the Sun, and lantern. This collection signifies the fact that the poet seems to have found his way. It is at this time that Sepehri learns about mysticism in the east: "In this collection he enters the world of mystic contemplation" (Abedi as cited in Emad, 1999, p. 44). This entrance to the world of mysticism functioned as a shifting phase for Sepehri. The next poems show that Sepehri is not going to apply darkness and grief. The darkness echoed in his 'Death of Colors' seem to fade away and move towards light. 
The fifth collection of Sepehri's poetry is "The Sound of the Water's Step." It is in fact a long poem, not a collection, and "Its main subject is death" (Shamissa, 1993, p. 121). Sepehri lost his father in his early teens. His father was Sohrab Sepehri's main teacher since his childhood and in addition to his academic education. He had taught Sepehri painting, music, and calligraphy. His mother, Forough Sepehri, was born and bred in a family fond of literature. She was truly loved by Sohrab and this can be clearly felt in a large number of his poems as in "I have a mother better than the leaf of a tree" (Sepehri, 2007, p. 272). His father's death inspires him to write this long poem.

Death is one of the philosophical concerns of Sepehri. He believes death accompanies life. Basically, beauty, joy and pleasure are indebted to death. As Ramshini (2006) says, "Like ancient mystics, Sepehri does not consider death as the termination of life, but his interpretation of death is very delicate, and religious. He considers the end of this life as a journey to a blue and peaceful firmament" (p. 182). The following parts aim at discussing this mystical attitude of Sepehri toward death.

In "And", he compares life to a sleep, and death to awakening, and also to blossoming. He writes,

"'Yes, we are the buds of a sleep.'

'The buds of a sleep? Do we blossom?'

'One day. Without any movement of a single leaf.'

'Here?'

'No, in the vallley of death.'

'Darkness, loneliness.'

'No, a beautiful seclusion"' (Sepehri, 2007, pp. 229-230).

Here death is depicted as a peaceful beginning. This concept of death can be under the influence of Islamic beliefs in particular and religious beliefs in general. Similarly, Donne in one of his sermons, Death's Duel, views death as "a birth - a beginning, for some, of immortal life" (Rugoff, 1962, p. 179). Again, comparatively this view of death is influenced by Donne's Christian beliefs.

To have a full understanding of death in Sepehri's works, one needs to understand his view of life. In "The Sound of the Water's Step" he writes,

"Life is a pleasant custom.

Life has wings as large as death.

The idea of smelling flower in another planet.

Life is washing a plate.

Life is finding a penny in the street gutter"

(Sepehri, 2007, pp. 289-290).
It is death which determines the breadth of life. Life for Sepehri is a simple phenomenon. "One can see it in any trivial action. Similarly death becomes simple, conceivable, and pleasant" (Ramshini, 2006: 183). To Sepehri, everything, even death, originates from a sacred rule. He believes death like any other fundamental rule of life is required so that all beings would be able to achieve perfection. The following are excerpts from his lengthy poem, "The Sound of the Water's Step".

Do not be afraid of death

Death is not the end of a pigeon.

Death is responsible for the beauty of the butterflies.

Death sometimes drinks Vodka.

Death sometimes sits in the sunshade and looks at us.

And all of us know

The lungs of pleasure are full of oxygen of death (Sepehri, 2007, pp. 296-97).

One should bear in mind that in mythology the pigeon is the symbol of exultation, life, spirit, freedom, flight, and peace (Ramshini, 2006, p. 184; Shamissa, 1993, p. 109). So 'death is not the end of pigeon' can be interpreted as death does not terminate life and peace. Death is responsible for the beauty of the wings of the butterfly. After a caterpillar is dead, a butterfly having beautiful wings is born. There is a hidden comparison between a caterpillar and human. Caterpillar is compared to human; cocoon to life in this world; and butterfly to human after death. When the creature's life as a caterpillar ends, it dies and turns into a butterfly. Human is the same. When his/her life in this transient world ends, s/he is transformed to a more beautiful world of afterlife. It can be compared to 'when one man dies, one chapter is not torn out of the book, but translated into a better language.'

Along with comparisons there are also illuminating contrasts in this line. How small is cocoon in contrast to this world? The same is the proportion between this world and the world after death. The butterfly is beautiful and can fly. Death beautifies human and enables him/her to fly. It refers to human's spiritual beauty and his/her absolute freedom after death. This single line reveals Sepehri's art in including many deep and subtle thoughts in a few simple words.

For Sepehri, life and death are interwoven, "the lungs of pleasure are full of oxygen of death." Every time one inhales s/he fill her/his lungs with oxygen. This filling perpetuates her/his life, and at the same time brings her/him a step nearer to her/his death. 
"Sepehri's view to death is like those great Iranian Sufists who believed life and death are indeed one, and death is the continuation of life" (Shamissa, 1993, p. 220).

In "The Sound of the Water's Step" he writes "the eyes should be washed, we should look the other way" (Sepehri, 2007, p. 291). Then, he continues and writes,

Let's not wish the fly scared off the fingers of the nature.

Let's not wish the panther wiped away from the scene of creation.

Life would lack something without worms.

The rules of the tree would suffer without caterpillars.

If there was no death, our hands would look for something

We should know if there was no light, the living logic of flight would alter (Sepehri, 2007, p. 294). He believes death is needed for our life as much as light is needed for flying. Here death is compared to light. Like Spinoza, Sepehri has a relativistic idea of good and bad. Based on this idea whatever we consider as bad is bad because it is not in harmony with our rules. We should bear in mind that death is in harmony with the rules of the nature. To Sepehri, life is a collection of simple and natural events and we are to look at them in a simple way without any kind of preconceptions. He believes we should cleanse our eyes and look at things differently so as to be able to find out that everything is in its right place and nothing can be ever considered as bad. There are some people who consider death as an undesirable and destructive phenomenon. Sepehri advises them to wash their eyes, in fact, to change their attitude toward death.

For Sepehri, death is a simple phenomenon; when it happens it does not affect life. Life is a continuous and perpetual movement that nothing can stop it. Thus, there is no reason to become depressed and sad when someone dies. As he believes Consolations are not few. In 'The Movement of the Word Life" he writes,

Life means: a starling flew away.

What made you gloomy?

Consolations are not few. For instance, this sun

Tomorrow's baby, next week's pigeon.

Somebody died last night.

And wheat bread is still delicious.

And water is still pouring down. The horses are drinking.

(Sepehri, 2007, pp. 386-387)

In "Path", he writes "neither you nor me last ... death came/ open the door" (Sepehri, 2007, p. 234). Sepehri accepts death, and is prepared to embrace it. He does not fear death, but this lack of fear does not lead to treating it with contempt as it is done in Holy Sonnet $X$ by Donne. His acceptance of death does not lead to idleness and indolence. On the contrary, he takes advantage of the smallest opportunities. He believes "while there are ponies one should live" (Sepehri, 2007 , p. 350). Pony is a short-lived flower. One should use even the shortest moments of life, and when death comes s/he should embrace it.

Sepehri's attitude toward death is -if not shaped byvery similar to Islamic Sufism and eastern mysticisms. He claims to have knowledge about Chinese, Japanese, Indian, and Iranian mysticism, which he attempts to portray in his poems. In an introduction to the first edition of his fourth book, Torrent of Sun, in 1961, he "explicitly addressed himself to the ideas about Sufism, Buddhism, and Hinduism, which preoccupied him throughout his life and which were to find their fullest expression in Mosafer " (Turner as cited in Salami \& Zahedi, 2007, p. 6). In his first book, he had a negative attitude toward death. As soon as he got familiar with mysticism this attitude changed. The positive attitude can be traced in book two, and as he continued his study of mysticism his positive attitude became clearer. He neither does demonstrate his contempt for death's pride, nor does emphasize the powerlessness of death, nor does attack the immortality and pride of death, nor does depict death's power and dominion on human. For him, death is not an unpleasant phenomenon, but a road that leads to redemption and resurrection. He is not afraid of death. Sepehri recognizes, accepts, and praises death.

\section{CONCLUSION}

Both John Donne and Sohrab Sepehri employ death as a subject for their artistic creation. Donne is a socalled 'death poet'. Philosophic speculations on subjects other than death appear in his works, and philosophic apprehensions concerning death and immortality occupy considerable space. Some of the reasons behind his fascination with death are similar to those of the other Renaissance, Jacobean, and Caroline artists. Among these reasons are the depression and cynicism of spirit; and regarding life as a cheap possession (Rugoff, 1962, p. 234). Donne has also some personal motives for using death in his works. The bereavement of his family members and loved ones manifested in Holly Sonnet XVII, A Nocturnal Upon Saint Lucy's Day, and An Anatomy of the World, his occupation as a preacher manifested in Death's Duel, the harassment of the Catholics, his poverty, "his lifelong ill-health" (Rugoff, 1962, p. 234), and the plagues which regularly attacked London qualify as these motives. 
Unlike Donne, Sepehri is not known as a 'death poet.' Although he lives in a turbulent period in the history of Iran, and experiences the coup of 1953, the oppressive atmosphere of the following years, and the revolution of 1979, he, unlike many of his contemporary artists, is not influenced by his immediate condition, and is severely criticized for it. In fact, his themes and subjects tend to be universal rather than time- and place-specific. He refers to death as much as -not more than- he refers to other fundamental questions of human.

Donne is inconsistent in his treatment of death. Throughout his literary career he vacillated between two poles. As a religious preacher, he has a positive attitude toward death, but as soon as he loses a beloved, his attitude changes. Sepehri, his first collection ignored, is consistent in his positive treatment of death. This positive attitude toward death is not affected even by the death of his beloved father. He views death as a road that leads to redemption and resurrection. Sepehri recognizes, accepts, and praises death. His view to death is like those great Iranian mystics who believed life and death are indeed one. Sepehri's consistency in the treatment of death has something to do with the poet's religious beliefs. The reason behind his consistency in treating death as a positive phenomenon is his familiarity with the Islamic Sufism and eastern mysticisms. The change of his attitude toward death coincided with his familiarity with mysticism. In a note written after the death of his father he refers to the role of religion to provide the modern man with a meaning of death and to distinguish it from annihilation (Sepehri as cited in Dianoush, 2006, p. 105).

\section{REFERENCES}

Abrams, M. H. (1987). The Norton anthology of English literature. $5^{\text {th }}$ ed. New York: W. W. Norton.

Anderson, L. (1995). 'Contraryes meete in one': A Psychobiography of John Donne. Available from University of Tennessee Honors Thesis Projects. Retrieved from http://trace.tennessee. edu/utk_chanhonoproj/1

Andreasen, N. J. C. (1967). John Donne: Conservative revolutionary. Princeton: Princeton University Press.

Carey, J. (1990). John Donne: Life, mind and art. London: Faber and Faber.

Dianoush, I. (2006). Naked with the earth. Tehran: Morvarid.

Donne, J. (2002). The complete poems of John Donne. London: Wordsworth Editions Limited.
Edgecombe, R. S. (1994). Donne's A Nocturnal Upon S. Lucy's Day, Being the Shortest Day. The Explicator, 52(3), 142-145.

Emad, H. (1999). To the garden of fellow travellers. Tehran: Ketab-e-Khoub.

Gosse, E. (2008). Edmund Gosse 'John Donne (1894). In H. Bloom (Ed.), John Donne and the Metaphysical Poets, (pp. 94-106). New York: Bloom's Literary Criticism.

Greenblatt, S., Abrams, M. H., Christ, C. T., David, A., Lewalski, B. K., Lipking, L., Logan, G. M., Lynch, D. S., Maus, K. E., Noggle, J., Ramazani, J., Robson, C., Simpson, J., Stallworthy, J., \& Stillinger, J. (2006). The Norton anthology of English literature. $8^{\text {th }}$ ed. New York: W. W. Norton.

Hammond, G. (1974). Nineteenth - and early twentieth-century criticism. In The metaphysical poets: A case book, (pp. 57-90). London: MacMillan Press.

Jungman, R. (2007). Mining for Augustinian gold in John Donne's meditation 17. ANQ, 20(2), 16-21.

Keenan, S. (2008). Renaissance literature. Edinburgh: Edinburgh University Press

Ponder, M. (1998). Gender and the religious vision: Katherine Lee Bates and poetic elegy. In J. L. Mahoney (Ed.), Seeing into the life of things: Essays on literature and religious experience, (pp. 171-194). Fordham: Fordham University Press.

Ramshini, M. (2006). Sohrab and Jibran. Mashhad: Farhangsaray-e-Mirdashti.

Rugoff, M. A. (1962). Donne's imagery: A study in creative sources. New York: Russell \& Russell.

Salami, E. \& Zahedi, A. (2007). Sohrab Sepehri: The water's footfall selected poems. Tehran: Zabankadeh.

Sepehri, S. (2007). The eight books. Tehran: Tahouri.

Shamissa, S. (1993). A glance at Sepehri. Tehran: Morvarid.

Smith, A. J. (1983). John Donne: The critical heritage. London: Routledge.

Stein, A. (1965). The burden of consciousness. In John Donne's lyrics: The eloquence of action, (pp. 163-197). Minneapolis: Lund Press.

Sugg, R. (2007). John Donne: Critical issues. New York: Palgrave MacMillan.

Targoff, R. (2008). John Donne, body and soul. London: The University of Chicago Press.

Trevor, D. (2000). John Donne and scholarly melancholy. Studies in English literature, 15001900, 40(1), 81-102.

Zhang, D. \& Wang, D. (2011). Death image in divine meditations of John Donne. Theory and Practice in Language Studies, 1, 861-864. 